\title{
Hepatocellular Copper Toxicity and Its Attenuation by Zinc
}

\author{
M. L. Schilsky, R. R. Blank, M. J. Czaja, M. A. Zern, I. H. Scheinberg, R. J. Stockert, and I. Sternlieb \\ Departments of Medicine and Biochemistry, and Marion Bessin Liver Research Center, \\ Albert Einstein College of Medicine, Bronx, New York 10461
}

\begin{abstract}
We studied the mechanisms by which excess copper exerts, and zinc mitigates, toxic effects on HepG2 cells. Survival and cell growth were reduced in media containing $>500 \mu \mathrm{M}$ copper chloride for $48 \mathrm{~h}$; $\mathrm{LD}_{50}$ was $750 \mu \mathrm{M}$. At 1,000 $\mu \mathrm{M}$ copper for $1 \mathrm{~h}$, there was a general reduction of protein synthesis, and no recognizable changes in cellular ultrastructure. Incubation of cells with $200 \mu \mathrm{M}$ zinc acetate before exposure to copper, raised the $\mathrm{LD}_{50}$ for confluent cells to $1,250 \mu \mathrm{M}$ copper chloride, improved protein synthesis, and increased synthesis of a 10-kD protein, apparently metallothionein. The mitigation, by zinc, of copper's toxicity may in part be mediated through induction of this protein in the hepatocyte.
\end{abstract}

\section{Introduction}

The mammalian liver is the primary target of toxicity in hereditary disorders of copper toxicosis: accumulation of copper in excess of metabolic requirements causes fatal hepatocellular injury (1). However, the mechanisms by which excess copper results in cellular toxicity have not been well defined despite in vitro studies that demonstrate alterations in membranes, proteins, and several hepatocellular enzymes and reduced stability of DNA (2); the demonstration in patients with Wilson's disease-hereditary copper toxicosis transmitted by a pair of abnormal autosomal recessive genes-and in mutant mice (3) and Bedlington terriers (4) of biochemical and pathologic abnormalities and ultrastructural changes in mitochondria, peroxisomes, endoplasmic reticulum, or lysosomes $(1,2)$; and our ability to treat some of these disorders effectively (2).

The mechanism by which various medications reverse copper toxicity in human beings $(2,5-7)$ has not been clearly defined. Zinc, an alternative agent being tested for the treatment of Wilson's disease $(6,7)$, is thought to act through inhibition of intestinal copper absorption. This action has been related in animal models to the induction of intestinal metallothionein (8).

In this study, using the human hepatoblastoma cell line, HepG2, which maintains a number of differentiated physiologic functions (9), we have investigated mechanisms of copper toxicity, and present evidence for hepatocellular protection

Address reprint requests to Dr. Schilsky, Liver Research Center, Albert Einstein College of Medicine, 1300 Morris Park Avenue, Bronx, NY 10461.

Received for publication 11 January 1988 and in revised form 31 May 1989.

J. Clin. Invest.

(c) The American Society for Clinical Investigation, Inc. 0021-9738/89/11/1562/07 \$2.00

Volume 84, November 1989, 1562-1568 by zinc, an effect which may be related to the synthesis of copper binding proteins.

\section{Methods}

Growth and survival. HepG2 cells obtained originally from Drs. Barbara P. Knowles and David P. Aden of the Wistar Institute were grown in $35-\mathrm{mm}$ plasticware dishes (Falcon Labware, Oxnard, CA) at $37^{\circ} \mathrm{C}$ under $5 \% \mathrm{CO}_{2} / 95 \%$ air in minimal essential media (MEM), which with $10 \%$ fetal bovine serum (FBS) is termed MEM+, containing $1.4 \mu \mathrm{M}$ copper. Cultures were fed on the second day after seeding and were studied when they reached confluence at day 5 , with each dish containing $\sim 1 \times 10^{6} \mathrm{HepG} 2$ cells. To investigate the effect of copper on cells in the exponential phase of growth, $\sim 1 \times 10^{5}$ cells were seeded in MEM+ with concentrations of copper chloride up to $1000 \mu \mathrm{M}$ (Fig. 1). The effect of copper on viability of confluent cells was determined by incubating cells in MEM+ containing copper chloride $(500-1,500 \mu \mathrm{M})$ for $48 \mathrm{~h}$ (Fig. 2, ๑). To determine the effect of zinc, the same experiment was performed after $2 \mathrm{~h}$ preincubation and the cells in MEM+ containing $200 \mu \mathrm{M}$ zinc acetate.

To estimate the duration of protection afforded by $2 \mathrm{~h}$, preincubation in MEM+ containing $200 \mu \mathrm{M}$ zinc acetate, cells were then incubated in MEM+ for up to $40 \mathrm{~h}$ before exposure to media containing 1,000 $\mu \mathrm{M}$ copper chloride (Fig. 3).

In both preceding experiments, the number of viable cells, those excluding trypan blue (10), was counted for and plotted as means \pm SD of duplicates in Fig. 2 or triplicates in Fig. 3.

Protein synthesis. Cells grown to confluence were washed with phosphate-buffered saline (PBS), pH 7.4, and incubated at $37^{\circ} \mathrm{C}$ in MEM + containing $1,000 \mu \mathrm{M}$ copper chloride for varying intervals up to $60 \mathrm{~min}$. Some preparations were preincubated in MEM+ containing $200 \mu \mathrm{M}$ zinc acetate for $2 \mathrm{~h}$, or containing $2 \mu \mathrm{g} / \mathrm{ml}$ cycloheximide for $1 \mathrm{~h}$, before exposure to MEM+ or copper media. After two washes with PBS, the cells were placed in $0.5 \mathrm{ml}$ of methionine-free MEM containing $100 \mu \mathrm{Ci} / \mathrm{ml}\left[{ }^{35} \mathrm{~S}\right]$ methionine for $10 \mathrm{~min}$, washed with icecold MEM followed by PBS, harvested by scraping, and suspended in 1 $\mathrm{ml}$ of PBS. Aliquots were obtained for determinations of acid-insoluble radioactivity, representing newly synthesized protein, by precipitation with an equal volume of $20 \%$ trichloroacetic acid (TCA) and adsorption onto glass fiber filters; for total protein determination, by the method of Lowry et al. (11); and for analysis by sodium dodecyl sulfate/polyacrylamide gel electrophoresis (SDS-PAGE). Cell lysates were prepared for electrophoretic analysis by centrifugation of the cell suspension in an Eppendorf centrifuge (Brinkmann Instruments Co., Westbury, NY) for $3 \mathrm{~min}$, and dissolution of the cell pellet into SDSPAGE sample buffer containing $1 \%$ SDS, $0.1 \mathrm{M}$ dithiothreitol (DTT), $10 \%$ glycerol, $0.05 \mathrm{M}$ Tris chloride, $\mathrm{pH} 6.7$, and phenol red. Equal amounts of protein from cell lysates were applied to each lane. After electrophoresis, the gel was fixed for $1 \mathrm{~h}$ in a solution of $10 \%$ acetic acid, 40\% methanol, soaked in 3 vol of Enhance (New England Nuclear, Boston, MA) for $45 \mathrm{~min}$, followed by water for $30 \mathrm{~min}$, dried under vacuum, and exposed to SB-5 x-ray film (Eastman Kodak Co., Rochester, NY) at $-70^{\circ} \mathrm{C}$.

Immunoprecipitation of albumin was performed in controls and in cells treated with $1,000 \mu \mathrm{M}$ copper chloride and labeled in methionine-free MEM, containing both $10 \%$ FBS which was dialyzed to reduce its intrinsic methionine content and $200 \mu \mathrm{Ci} / \mathrm{ml}\left[{ }^{35} S\right]$ methionine for $30 \mathrm{~min}$. Cells were washed in PBS, harvested by scraping, and then centrifuged at $1,000 \mathrm{rpm}$ for $5 \mathrm{~min}$. The resulting pellet was placed into 


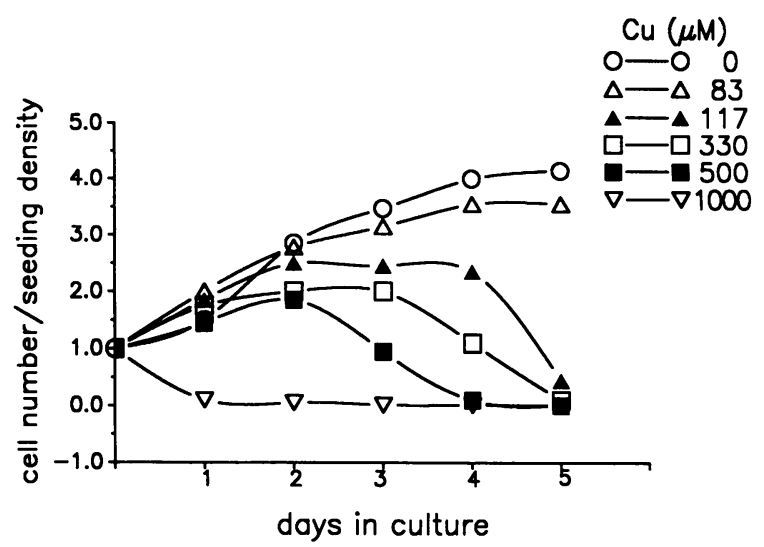

Figure 1. Survival and growth of HepG2 in the presence of copper. Cells $\left(\sim 1 \times 10^{5}\right.$ per dish) were plated in media without and with increasing concentrations of added copper chloride. Each point represents the mean of triplicate determinations of numbers of surviving cells.

$1 \mathrm{ml}$ of ice-cold lysis buffer containing $0.15 \mathrm{M} \mathrm{NaCl}, 1 \%$ of the nonionic detergent Nonidet (NP40), $2 \mu \mathrm{M}$ phenylmethylsulfonyl fluoride, $1 \mathrm{mM}$ EDTA, $10 \mathrm{mM}$ Tris, and $1 \mathrm{mg} / \mathrm{ml}$ bovine serum albumin, $\mathrm{pH}$ 7.4 for $10 \mathrm{~min}$. Ten microliters of rabbit anti-human albumin antibody (Cooper Biomedical, Inc., Malvern, PA), were added to the mixture and incubated at $4^{\circ} \mathrm{C}$ overnight, followed by the addition of $50 \mu \mathrm{l}$ of a $20 \%$ suspension of protein A-Sepharose for $2 \mathrm{~h}$ at $4^{\circ} \mathrm{C}$. Each sample was centrifuged, the pellet washed four times in ice-cold buffer containing $0.15 \mathrm{M} \mathrm{NaCl}, 50 \mathrm{mM}$ Tris, $1 \%$ Triton, $0.1 \%$ SDS, and $0.5 \%$ deoxycholate, $\mathrm{pH} 7.4$; once in a solution of $25 \mathrm{mM}$ Tris, $0.15 \mathrm{M} \mathrm{NaCl}$, pH 7.4; and placed in $100 \mu \mathrm{l}$ of SDS-PAGE gel sample buffer at $80^{\circ} \mathrm{C}$ for $1 \mathrm{~h}$, and $100^{\circ} \mathrm{C}$ for $10 \mathrm{~min}$, which was centrifuged with aliquots of the supernatant removed for protein assays. Equal amounts of protein were applied to each lane and resolved by 10\% SDS-PAGE before autoradiography (see Fig. 7).

Radiolabeling of control and zinc pretreated cells with $\left[{ }^{35} \mathrm{~S}\right] \mathrm{cysteine}$ was performed in cysteine-free RPMI 1640 (Gibco Laboratories, Grand Island, NY) media containing $10 \%$ dialyzed FBS and $50 \mu \mathrm{Ci} / \mathrm{ml}$ $\left[{ }^{35}\right.$ S]cysteine for $1 \mathrm{~h}$. To cell lysates, prepared as described, 1 vol of acetone was added and the mixture was centrifuged at $10,000 \mathrm{~g}$. The supernatant was saved and treated with $3 \mathrm{vol}$ of acetone and recentrifuged (12). The resulting pellet was retained and dissolved in PBS containing $10 \mathrm{mM}$ DTT under nitrogen for $4 \mathrm{~h}$ at room temperature, treated with $20 \mathrm{mM}$ iodoacetamide at $37^{\circ} \mathrm{C}$ for $30 \mathrm{~min}$, followed by the addition of SDS-PAGE sample buffer with 0.1 M DTT. Samples con-

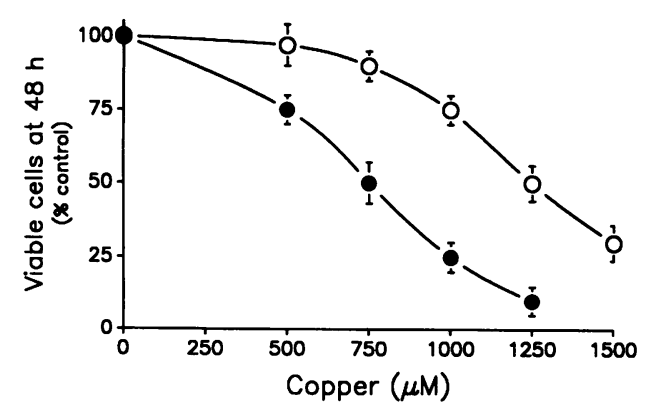

Figure 2. Survival of confluent HepG2 in the presence of copper with (O) or without (๑) pretreatment with $200 \mu \mathrm{M}$ zinc acetate for 2 h. Cells were grown to confluence $\left(1.5 \times 10^{6}\right.$ per dish $)$ and then exposed to media containing various concentrations of copper chloride for $48 \mathrm{~h}$. The number of viable cells was determined as in Fig. 1, and expressed as the means $\pm \mathrm{SD}$ of the percentage of cells maintained in normal growth media.

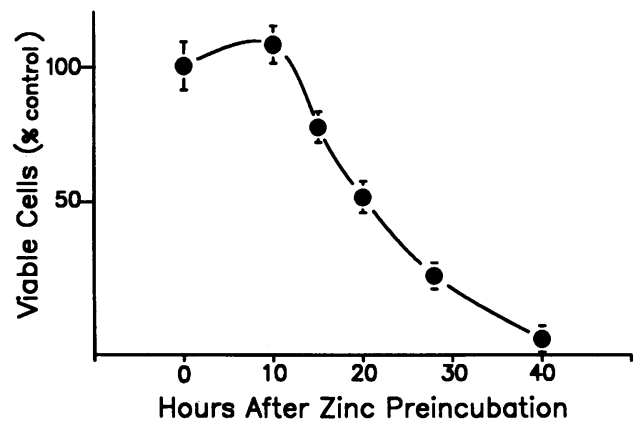

Figure 3. Duration of the effect of zinc on cellular survival of cells exposed to copper for $48 \mathrm{~h}$. HepG2 cells were preincubated with media containing zinc acetate $(200 \mu \mathrm{M})$ for $2 \mathrm{~h}$, returned to normal growth media for periods of up to $40 \mathrm{~h}$, and incubated for $48 \mathrm{~h}$ with copper chloride $(1,000 \mu \mathrm{M})$. Only $25 \%$ of cells exposed to $1,000 \mu \mathrm{M}$ copper alone survive for $48 \mathrm{~h}$ (see Fig. 2).

taining equal amounts of protein were applied to each lane and resolved by electrophoresis on a 10-20\% gradient SDS-PAGE before autoradiography.

Metallothionein was detected immunologically by Western blot technique (13) using an antibody raised in sheep against rat metallothionein (kindly provided by Dr. I. Bremner, Aberdeen, Scotland), which we have tested for cross-reactivity to human metallothionein. Samples were prepared for electrophoresis by lysis in $1 \%$ SDS, followed by reduction and alkylation as described above. After electrophoresis, the proteins were transferred to nitrocellulose soaked in a buffer containing $48 \mathrm{mM}$ Tris, $39 \mathrm{mM}$ glycine, $0.04 \%$ SDS, and $20 \%$ methanol, using a Novablot apparatus (LKB Instruments, Inc., Gaithersburg, $\mathrm{MD})$. Blocking of the nitrocellulose was done using a $2 \%$ solution of nonfat dry milk, and bound antibody was detected using ${ }^{125} \mathrm{I}$-protein A followed by exposure to XAR-5 film (Eastman Kodak Co.) at $70^{\circ} \mathrm{C}$.

To determine the profile of $\left[{ }^{35} \mathrm{~S}\right]$ cysteine labeling of proteins in $100,000-g$ supernatants from control and zinc-pretreated cells, confluent HepG2 cells were incubated in MEM+ or MEM+ with $200 \mu \mathrm{M}$ zinc acetate for $2 \mathrm{~h}$. The cells were then radiolabeled with $50 \mu \mathrm{Ci} / \mathrm{ml}$ $\left[{ }^{35}\right.$ S]cysteine for $2 \mathrm{~h}$ in cysteine-free MEM with $10 \%$ dialyzed FBS and $50 \mu \mathrm{M}$ copper chloride (the last being added for labeling experiments so conditions would remain constant for these and parallel experiments in which the copper contents of the fractionated $100,000-g$ supernatants were determined). After labeling, the cells were washed in ice-cold MEM+, harvested by scraping, and centrifuged at $1,000 \mathrm{rpm}$ for $5 \mathrm{~min}$. The pellets were then homogenized in $10 \mathrm{mM}$ Tris, $\mathrm{pH} 7.7$, and the homogenates centrifuged at $100,000 \mathrm{~g}$ for $1 \mathrm{~h}$. The resulting supernatant was assayed for protein content, and fractionated by HPLC gel filtration using a Zorbax GF-250 column (Dupont Co., Wilmington, DE). Radioactivity was measured using an LKB Instruments Rackbeta counter.

Glutathione levels and synthesis. Cellular levels of glutathione were determined by the method of Sekune and Ando (14) which detects cellular glutathione by its reaction with a maleimide compound, 10-(maleimido)-2,3,6,7-tetrahydro-11-oxo-1 H,5H,11H-(1)-benzopyrano 6,7,8-1,quinolizine (BACM, Polysciences, Inc., Warrington, PA), yielding a fluorescent thiol derivative. Measurements of fluorescence were made using a fluorescence spectrophotometer (Perkin-Elmer Corp., Norwalk, CT) with an excitation wavelength of $400 \mathrm{~nm}$, an emission wavelength of $500 \mathrm{~nm}$, and a slit of $10 \mathrm{~nm}$. Levels of reduced glutathione were determined in the supernatant of TCA precipitates prepared from cell homogenates after cellular incubation in MEM+ alone, or with MEM+ containing $200 \mu \mathrm{M}$ zinc for $2 \mathrm{~h}$. Reduced glutathione was used for standard measurements. Aliquots of the homogenates were used for determination of cellular protein by the method of Lowry et al. (11) for each triplicate sample.

Thin-layer chromatography was used to determine if newly synthesized glutathione was present in fractions $26-28$ obtained by HPLC gel 
filtration of the $100,000-g$ supernatants of radiolabeled control and zinc-pretreated cells prepared as described above. Aliquots of these pooled fractions and a reduced glutathione standard were spotted onto a silica gel thin-layer plate and resolved in $n$-butanol-acetic acid-pyridine-water (15:3:10:12). After $5 \mathrm{~h}$ the plate was dried and reacted with ninhydrin, and positive regions were noted. The plate was then placed in a paper casette with XAR film and exposed at $-70^{\circ} \mathrm{C}$ for 1 wk.

Cellular ATP. Levels of cellular ATP were determined by a modification (15) of the method of Lamprecht and Trautschold. HepG 2 cells were grown to confluence in $25-\mathrm{cm}^{2}$. culture flasks and incubated with $\mathrm{MEM}+$ alone, or treated with MEM+ containing 1,000 $\mu \mathrm{M}$ copper chloride for $1 \mathrm{~h}$. After treatment, the cells were washed with PBS and harvested by scraping into ice-cold $3 \%$ perchloric acid. The suspension was centrifuged at $10,000 \mathrm{rpm}$ for $3 \mathrm{~min}$, and the amount of ATP in the supernatant was determined for triplicate samples from duplicate experiments. The amount of acid-precipitable protein was determined for each sample by the method of Lowry et al. (11).

RNA synthesis. For the measurement of total RNA synthesis, confluent HepG2 cells were incubated in MEM+ containing $100 \mu \mathrm{Ci} / \mathrm{ml}$ of $\left[{ }^{3} \mathrm{H}\right]$ deoxyuridine, and with the same media containing either 1,000 $\mu \mathrm{M}$ copper chloride or $200 \mu \mathrm{M}$ zinc acetate for $1 \mathrm{~h}$. The cells were washed with iced PBS, harvested by scraping, and suspended in PBS. Protein and radioactivity in TCA precipitates were determined in aliquots of the suspension.

Total RNA was extracted from cells grown to confluence in MEM+, and these cells incubated in MEM+ containing $1,000 \mu \mathrm{M}$ copper chloride for $1 \mathrm{~h}$; or in MEM+ containing $200 \mu \mathrm{M}$ zinc acetate for $2 \mathrm{~h}$ by homogenization of the cells in guanidine thiocyanate, and centrifugation through a cesium chloride gradient using a modification of the Chirgwin procedure $(16,17)$. Albumin and metallothionein mRNA levels were determined by means of Northern blot hybridization. Equal amounts of total RNA $(10 \mu \mathrm{g})$ were denatured in $0.5 \mathrm{M}$ glyoxyl, $50 \%$ dimethyl sulfoxide, and $10 \mathrm{mM}$ phosphate buffer, subjected to electrophoresis in a $1 \%$ agarose gel, transferred to a GeneScreen filter (New England Nuclear), and baked under vacuum for $2 \mathrm{~h}$ at $80^{\circ} \mathrm{C}$. After prehybridization, the filters were hybridized with a human albumin cDNA probe HSAF-47 (kindly provided by Dr. R. Lawn, Genentech, Inc., South San Francisco, CA) (18) or with a metallothionein cDNA probe for MT IIA, (kindly provided by Dr. Dean Hamer, National Cancer Institute, Bethesda, MD) (19), labeled with $\left.{ }^{32} \mathrm{P}\right] \mathrm{dCTP}$ to a specific activity of $2-5 \times 10^{8} \mathrm{cpm} / \mu \mathrm{g}$ DNA using a primer extension kit (International Biotechnologies, Inc., New Haven, CT). After hybridization the filters were washed under stringent conditions and exposed to XAR-5 film at $-70^{\circ} \mathrm{C}$.

Copper uptake and metabolism. To measure the effect of zinc on copper uptake, confluent cells grown in 96-well tissue culture plates (Flow Laboratories, Inc., McLean, VA) were preincubated in MEM+ containing $0-500 \mu \mathrm{M}$ zinc acetate, and then washed before incubation in MEM with carrier-free ${ }^{67} \mathrm{Cu}$ (Los Alamos National Laboratory) (20) or the same concentrations of zinc acetate in MEM at the time of copper uptake. At 30 or $60 \mathrm{~min}$, the incubation medium was aspirated and the cells were washed with $50 \mathrm{nM}$ sodium phosphate, $0.15 \mathrm{M}$ $\mathrm{NaCl}, \mathrm{pH} 7.2$, with $2 \mathrm{mM}$ EDTA at $4^{\circ} \mathrm{C}$ before lysis with $1.0 \mathrm{ml}$ of $1 \mathrm{~N}$ $\mathrm{NaOH}$ and measurements of radioactivity and total protein.

To determine the copper profiles of $100,000-g$ supernatants of HepG2 with and without zinc pretreatment, supernatants containing equal amounts of protein, identically prepared as described above for $\left[{ }^{35}\right.$ S $]$ cysteine labeling, were fractionated by HPLC gel filtration. Addition of $50 \mu \mathrm{M}$ copper to the incubation media of zinc-pretreated and control cells facilitated the measurement of copper by graphite furnace atomic absorption spectroscopy (21). These experiments were performed using copper-free glassware and polypropylene plastic tubes, and all solutions were made with double distilled and deionized water.

Cell ultrastructure. HepG2 cells grown to confluence in MEM+ were incubated in MEM+ containing 1,000 $\mu \mathrm{M}$ copper chloride for 1 and $3 \mathrm{~h}$; or in MEM+ containing $500 \mu \mathrm{M}$ copper chloride for $12 \mathrm{~h}$. Cells were harvested by scraping and suspended in PBS. Pellets obtained after centrifugation of cell suspensions were fixed for $1 \mathrm{~h}$ in a

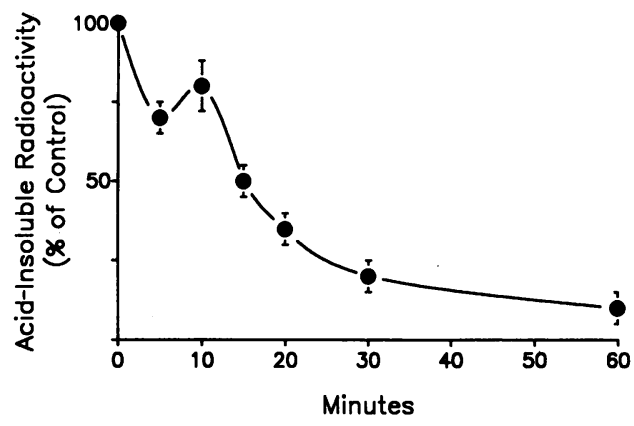

Figure 4. Rate of protein synthesis by HepG2, as a function of time, after exposure to $1,000 \mu \mathrm{M}$ copper. The rate of synthesis was estimated by the incorporation of $\left.{ }^{35} \mathrm{~S}\right]$ methionine $(100 \mu \mathrm{Ci} / \mathrm{ml}$ for 10 $\mathrm{min})$ in TCA precipitates of cell lysates. Means \pm SD of four experiments are expressed as the percent of radioactivity measured in untreated cells.

chilled $1 \%$ osmium tetroxide solution containing barbital buffer, $\mathrm{pH}$ 7.4 , and processed for embedding in Epon. Fine sections were stained with uranyl acetate and lead citrate and examined under an electron microscope (Elmiskop I; Siemens-Allis Inc., Cherry Hill, NJ).

\section{Results}

Growth and survival. The number of viable HepG2 cells initially seeded at $1 \times 10^{5}$ cells per dish) in media containing increasing concentrations of copper, was little different from controls at day 1 for all copper concentrations between 83 and $500 \mu \mathrm{M}$ (Fig. 1). The numbers of viable cells continued to increase at a rate slightly less than controls from days $2-5$ or cells maintained in media containing up to $83 \mu \mathrm{M}$ copper, whereas higher concentrations of copper inhibited cell growth and increased cell death over time.

Confluent HepG2 cells incubated in media containing increasing concentrations of copper exhibited a dose-dependent reduction in cellular survival with an $\mathrm{LD}_{50}$ of $750 \mu \mathrm{M}$ (Fig. 2). Preincubation of confluent HepG2 cells for $2 \mathrm{~h}$ in growth media containing $200 \mu \mathrm{M}$ zinc acetate before exposure to copper increased the $\mathrm{LD}_{50}$ to $1,250 \mu \mathrm{M}$, and enhanced cellular survival for all copper concentrations tested. Zinc alone did not affect the number of viable cells. This effect extended to $\sim 30 \mathrm{~h}$ beyond the period of initial zinc treatment (Fig. 3).

Protein synthesis. The incorporation of $\left.{ }^{35} \mathrm{~S}\right]$ methionine by HepG2 into TCA-precipitable radioactivity was determined in cells incubated in 1,000 $\mu \mathrm{M}$ copper chloride for intervals up to $60 \mathrm{~min}$ (Fig. 4). An initial rapid reduction of the rate of synthesis appears to be followed by an interval during which incorporation of $\left[{ }^{35} S\right]$ methionine levels off for several minutes before a progressive decrease in protein synthesis occurs. Incubation for $2 \mathrm{~h}$ in $200 \mu \mathrm{M}$ zinc did not affect the rate of protein synthesis.

A generalized reduction in protein synthesis was observed at $1 \mathrm{~h}$ for cells exposed to $1,000 \mu \mathrm{M}$ copper chloride when newly synthesized proteins were examined using SDS-PAGE and autoradiography (Fig. 5). Protein synthesis, measured by the amount of ${ }^{35} \mathrm{~S}$ present in the TCA precipitate after a 10 min incubation, continued at $80 \pm 5 \%$ of control levels in cells exposed to $1,000 \mu \mathrm{M}$ copper chloride after preincubation in medium containing $200 \mu \mathrm{M}$ zinc acetate for $2 \mathrm{~h}$. The banding pattern obtained by SDS-PAGE analysis of $\left[{ }^{35} \mathrm{~S}\right]$ methioninelabeled proteins from zinc-treated cells did not differ substan- 


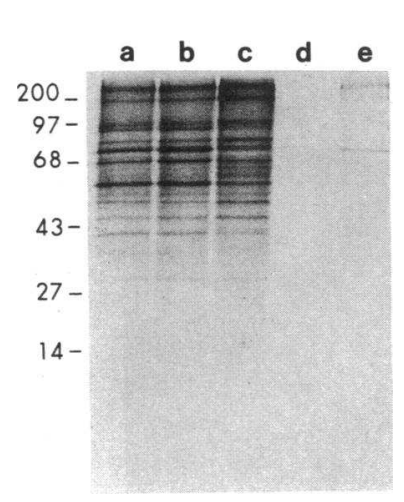

Figure 5. Autoradiographs of newly synthesized proteins resolved by $10 \%$ SDS-PAGE. Cells, treated with $(a)$ no additional copper, $(b)$ zinc acetate $(200 \mu \mathrm{M})$ for $2 \mathrm{~h},(c)$ zinc acetate $(200 \mu \mathrm{M})$ for $2 \mathrm{~h}$ followed by copper chloride $(1,000 \mu \mathrm{M})$ for $1 \mathrm{~h},(d)$ cycloheximide $(2 \mu \mathrm{g} / \mathrm{ml})$ for $1 \mathrm{~h}$, or $(e)$ copper chloride $(1,000 \mu \mathrm{M})$ for $1 \mathrm{~h}$, were then incubated with $\left[{ }^{35} \mathrm{~S}\right] \mathrm{me}$ thionine $(100 \mu \mathrm{Ci} / \mathrm{ml})$ for $10 \mathrm{~min}$. Molecular weight markers are $\times 10^{3}$. tially from that of controls, although the intensities of certain bands varied in the first three preparations (Fig. 5, $a-c$ ).

Pretreatment with zinc before incorporation of $\left[{ }^{35} \mathrm{~S}\right]$ cysteine resulted in increased synthesis of a 10-kD protein (Fig. 6), which was identified as metallothionein by Western blot (Fig. 7). The steady-state level of metallothionein increased over time for up to $48 \mathrm{~h}$, however, biosynthesis of this protein, as shown by $\left.{ }^{35} \mathrm{~S}\right]$ cysteine incorporation into metallothionein (Fig. 7), was increased $2 \mathrm{~h}$ after zinc pretreatment and returned to basal levels by $48 \mathrm{~h}$.

The profile of radioactivity of the fractions obtained by HPLC gel filtration of the $100,000-g$ supernatant after exposure to $\left[{ }^{35}\right.$ S]cysteine of zinc-pretreated cells suggests an increased incorporation of cysteine into low-molecular-mass fractions (Fig. $8 a$ ). The first peak, at fractions 22-23, represents retention times corresponding to purified metallothionein, consistent with the data obtained by SDS-PAGE.

Glutathione levels and synthesis. HPLC gel filtration of cytosol from $\left[{ }^{35} S\right]$ cysteine-labeled, zinc-treated HepG2 yielded two low-molecular-mass peaks with a high content of ${ }^{35} \mathrm{~S}$. Fractions 22-23 corresponded to the retention time of metallothionein (Fig. 8 a). The second peak, fractions 26-28, was subjected to thin-layer chromatography and resolved with the same $\mathbf{R f}$ as that of reduced glutathione (data not shown).

Despite an apparent increased synthesis of glutathione during the early phase after zinc treatment (Fig. $8 a$ ), the steady-state level of the peptide remained unchanged (glutathione content of zinc-treated and control cells, $1.9 \pm 0.1$ and $2.13 \pm 0.04 \mu \mathrm{g} / \mathrm{mg}$ protein, respectively).

Cellular ATP. Levels of cellular ATP were virtually unaltered after HepG2 exposure to MEM+ with $1,000 \mu \mathrm{M}$ copper for $1 \mathrm{~h}$. The levels of ATP in copper treated and control cells

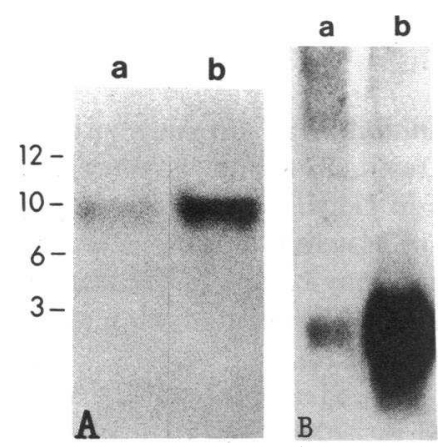

Figure 6. (A) Autoradiograph of metallothionein containing $\left[{ }^{35}\right.$ S]cysteine. (a) Cells incubated in MEM+; $(b)$ cells treated with MEM+ containing zinc acetate $(200 \mu \mathrm{M})$ for 2 h. Molecular weight markers are $\times 10^{3}$. (B) Metallothionein mRNA levels as determined by Northern blot analysis in (a) untreated cells and (b) HepG2 treated with zinc acetate $(100 \mu \mathrm{M})$ for $10 \mathrm{~h}$. Exposure time was increased in order to demonstrate the low levels of metallothionein-mRNA present in untreated cells.

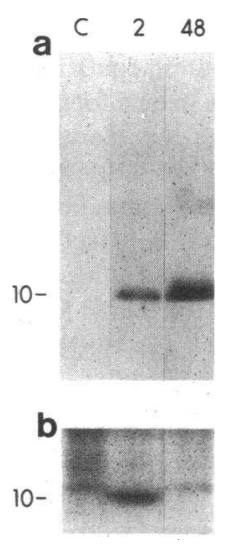

Figure 7. Time course of metallothionein steady-state levels and biosynthesis. (a) Western blot analysis of control cell lysates $(C)$, cell lysates prepared 2 and $48 \mathrm{~h}$ after zinc pretreatment $(2,48)$, resolved on $10-20 \%$ gradient SDSPAGE. A single 10-kD band (10) corresponding to metallothionein can be detected in the 2- and 48-h lanes. (b) Autoradiograph of $\left[{ }^{35} S\right]$ cysteinelabeled cell lysates resolved on $10-20 \%$ SDSPAGE. Only a relevant portion of the autoradiograph is shown. Note that the $10-\mathrm{kD}$ band displays the highest intensity at $2 \mathrm{~h}$.

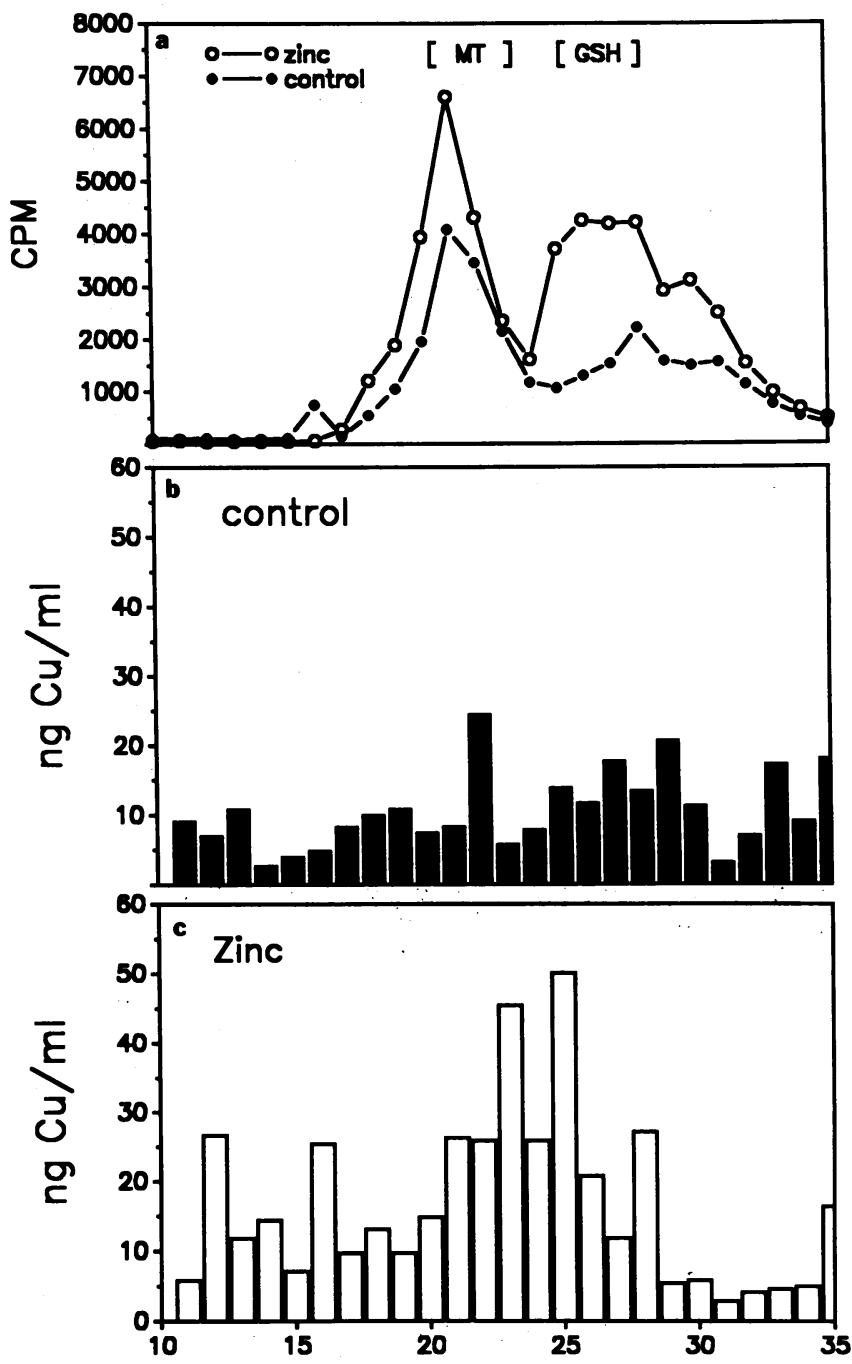

Figure 8. HPLC gel filtration elution profile of $100,000-g$ supernatants of zinc-pretreated and control cells. The mobile phase containing $10 \mathrm{mM}$ Tris, $0.15 \mathrm{~m} \mathrm{NaCl}, \mathrm{pH} 7.79$, was run at a flow rate of 1 $\mathrm{ml} / \mathrm{min}$. Fractions were collected at 0.5 -min intervals. Radioactivity and copper concentrations were corrected for protein contents of the sample. Results of a representative experiment performed in duplicate are presented. Indicated in brackets are the fractions in which a standard human metallothionein was detected, and those in which glutathione standards were recovered. (a) Profile of $\left[{ }^{35}\right.$ S $]$ cysteinelabeled fractions. (b) Copper content of fractions from control cells. (c) Copper content in zinc-pretreated cells. 


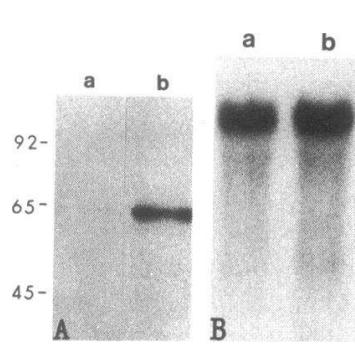

Figure 9. (A) Autoradiograph of immunoprecipitated albumin containing $\left[{ }^{35} \mathrm{~S}\right]$ methionine. Cells treated for $1 \mathrm{~h}$ with (a) MEM with copper chloride $(1,000 \mu \mathrm{M})$, or $(b) \mathrm{MEM}+$. (B) Albumin mRNA levels demonstrated by Northern blot analysis in (a) HepG2 treated with MEM+ or $(b)$ MEM with copper chloride $(1,000 \mu \mathrm{M})$ for $1 \mathrm{~h}$.

were $32 \pm 1.2$ and $36.0 \pm 2.0 \mathrm{nmol} / \mathrm{mg}$ protein, respectively, similar to those reported for isolated hepatocytes (15).

$R N A$ synthesis. There was a $39 \pm 5 \%$ increase in total RNA synthesis in cells treated for $1 \mathrm{~h}$ with $1,000 \mu \mathrm{M}$ copper compared to controls as measured by the incorporation of $\left[{ }^{3} \mathrm{H}\right] \mathrm{de}-$ oxyuridine. However, in zinc-pretreated cells exposed for $1 \mathrm{~h}$ to $1,000 \mu \mathrm{M}$ copper chloride the incorporation of uridine was reduced to $86 \pm 8 \%$ of control levels.

Immunoprecipitation of albumin containing $\left[{ }^{35}\right.$ S]methionine from cells treated for $1 \mathrm{~h}$ with $1,000 \mu \mathrm{M}$ copper chloride demonstrated a marked reduction of newly synthesized protein (Fig. $9 \mathrm{~A}$ ), in line with the generalized reduction of cell protein synthesis (Fig. 5). However, there was no demonstrable change in albumin mRNA levels from identically treated cells (Fig. 9 B).

Zinc treatment resulted in the induction of metallothionein mRNA (Fig. $6 \mathrm{~B}$ ), consistent with this effect on the cellular synthesis and steady-state level of this protein (Fig. 7).

Copper uptake and incorporation. The amount of cell-associated copper after a 30 - or 60 -min incubation in MEM containing ${ }^{67} \mathrm{Cu}$ was essentially unaltered by the coincubation of cells with $200 \mu \mathrm{M}$ zinc acetate (Table I). Incubation of the cells with $500 \mu \mathrm{M}$ zinc acetate for 60 min resulted in a slight decrease in total cell-associated copper compared with controls, however, there were no detectable differences at $30 \mathrm{~min}$. Preincubation with media containing 0-500 $\mu \mathrm{M}$ zinc acetate did not alter total cell-associated copper (data not shown).

Zinc pretreatment increased the amount of copper present in the low-molecular-mass fractions obtained by HPLC gel filtration (Fig. 8, $b$ and $c$ ). The fractions with an apparent $M_{\mathrm{r}}$ of 10-30 kD correspond to fractions containing metallothionein and demonstrate increased $\left[{ }^{35} \mathrm{~S}\right]$ cysteine incorporation. The peak in the lower-molecular-mass region containing $\left[{ }^{35} \mathrm{~S}\right]$ cys-

Table I. Effect of Zinc on Copper Uptake in HepG2

\begin{tabular}{ccc}
\hline & \multicolumn{2}{c}{ Total cell-associated copper } \\
\cline { 2 - 3 } Added zinc & $30 \mathrm{~min}$ & $60 \mathrm{~min}$ \\
\hline$\mu M$ & \multicolumn{3}{c}{$p g / \mathrm{mg}$ protein } \\
0 & 390 & 550 \\
200 & 410 & 590 \\
400 & 370 & 430
\end{tabular}

To determine the effect of zinc on copper uptake in HepG2, cells were coincubated with media containing added zinc acetate and ${ }^{67} \mathrm{Cu}$ for up to $60 \mathrm{~min}$. Results are the means of at least four determinations of total cell-associated ${ }^{67} \mathrm{Cu}$, with standard deviations of $\leqslant 10 \%$ for all data. The nonspecific cell-associated copper was determined by similar experiments at $4^{\circ} \mathrm{C}$, and was $<1 \%$ of copper bound at 30 min.

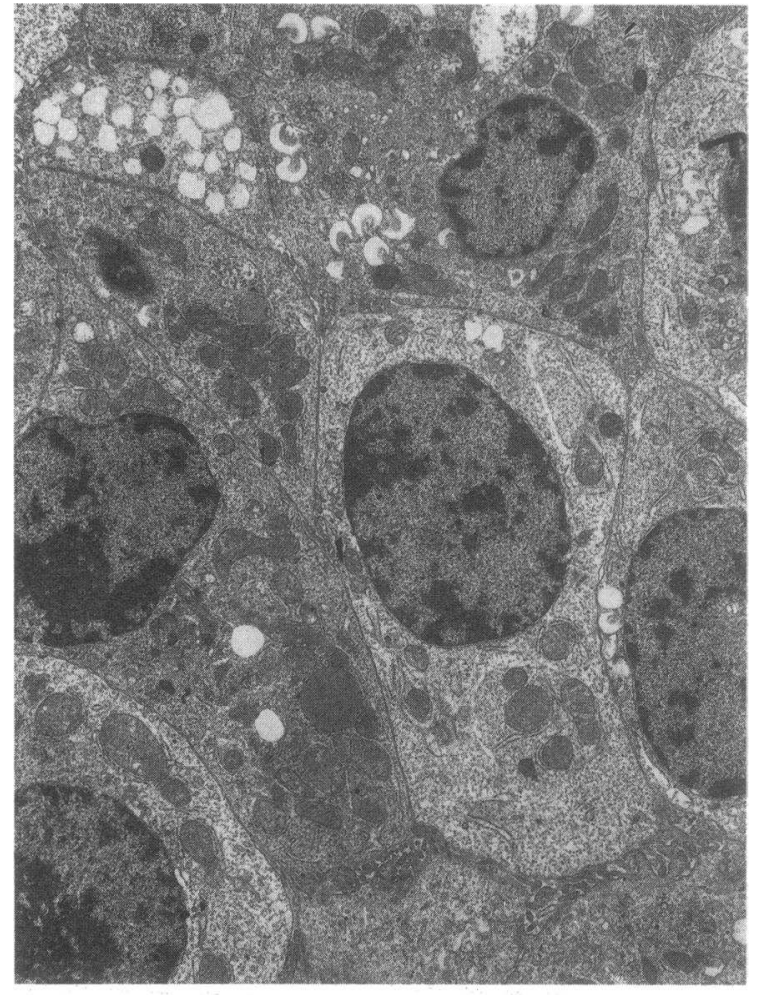

Figure 10. Low-power electron micrograph of HepG2 incubated in media containing copper chloride $(1,000 \mu \mathrm{M})$ for $1 \mathrm{~h}$. Except for the presence of scattered cytoplasmic vacuoles, the appearance of the cells is essentially normal. $\times 3,400$.

teine after zinc pretreatment appears to present glutathione (see above).

Cell ultrastructure. HepG2 cells exposed for $1 \mathrm{~h}$ to 1,000 $\mu \mathrm{M}$ copper chloride showed no abnormal ultrastructural changes (Fig. 10). After $3 \mathrm{~h}$ of exposure, the cells appeared pleomorphic, demonstrating a loss of intercellular attachments with widening of intercellular spaces, resulting in cell separation (Fig. 11). There was also disruption of the endoplasmic reticulum and vacuolization of the cytoplasm. At high magnifications, dense bodies that had the appearance of lysosomal granules, became visible in the cytoplasm. Mitochondria appeared unaltered. After a 12-h exposure to $500 \mu \mathrm{M}$ copper chloride (Fig. 12), profound disruption of the endoplasmic reticulum, condensation and vacuolization of the mitochondrial matrix, nuclear changes, and marked cellular pleomorphism were seen. Many cells were in various stages of degeneration.

\section{Discussion}

Acute copper toxicity causes inhibition of growth, shortened survival, the appearance of ultrastructural abnormalities, and inhibition of protein synthesis in HepG 2 cells. The early occurrence of marked inhibition of protein synthesis, before evidence of ultrastructural changes, may be one of the primary toxic actions of copper, resulting in disruption of cell metabolism and ultimately leading to cell death.

After cellular exposure to $1,000 \mu \mathrm{M}$ copper for $1 \mathrm{~h}$, the rate of protein synthesis is reduced by $>80 \%$. This reduction is generalized, affecting most cellular proteins (Fig. 5). The copper-induced inhibition of protein synthesis appears to be me- 


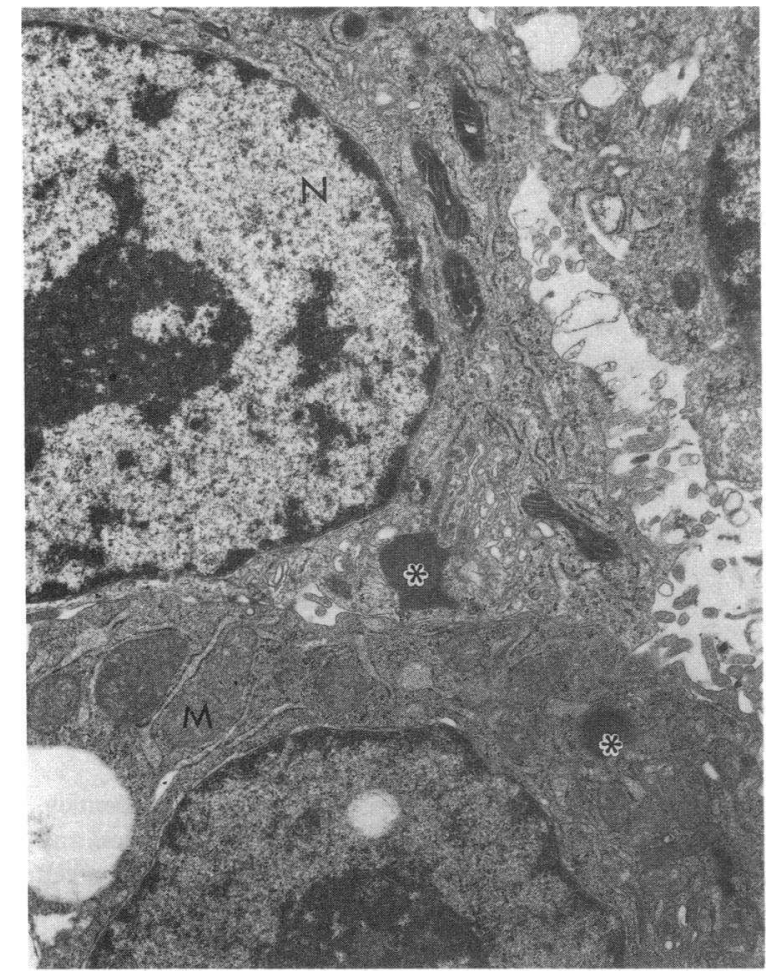

Figure 11. Electron micrograph of HepG2 incubated in media containing copper chloride $(1,000 \mu \mathrm{M})$ for $3 \mathrm{~h}$. Note loss of cell adhesion and the appearance of dense cytoplasmic bodies (*). $M$, mitochondrion; $N$, nucleus. $\times 8,500$.

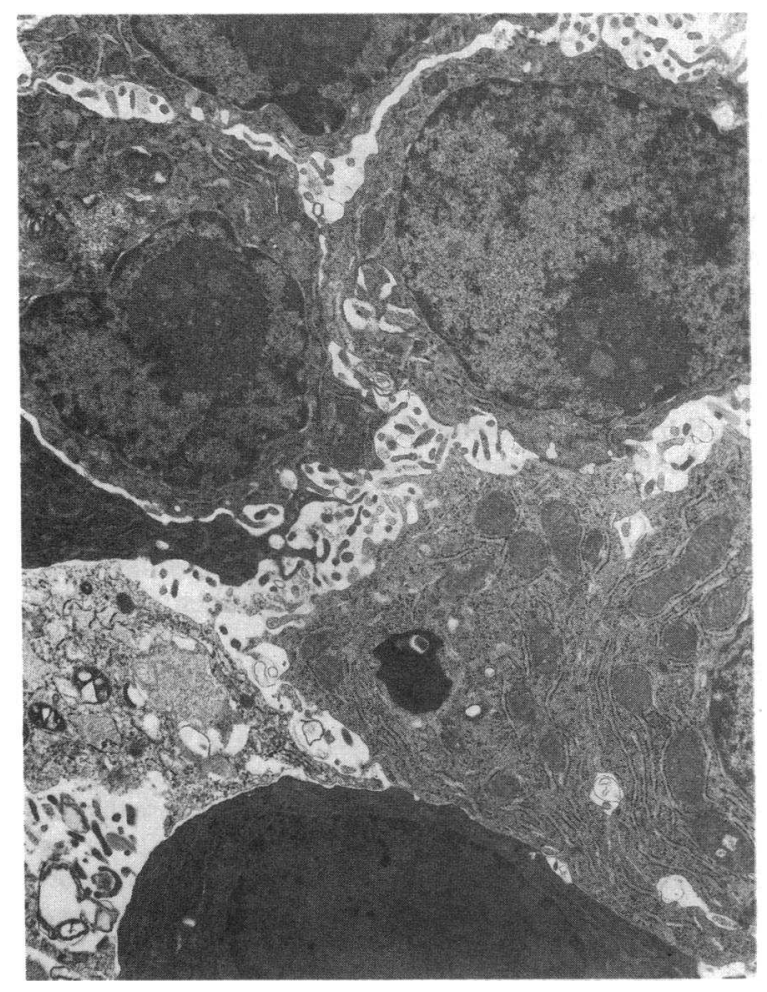

Figure 12. Electron micrograph of HepG2 incubated in media containing copper chloride $(500 \mu \mathrm{M})$ for $12 \mathrm{~h}$. Marked degenerative changes, condensation of cytoplasm and cellular pleomorphism are seen. $\times 6,800$. diated by an effect on the cellular translational machinery since cellular ATP remains unaltered, whereas total RNA synthesis is increased and the level of albumin-mRNA does not change (Fig. $9 \mathrm{~B}$ ). Prior studies have demonstrated that elevated tissue copper levels are associated with disruption of polysomes in rabbit liver and endometrial tissues (22), and that copper may have an indirect action upon the state of phosphorylation of some of the translation factors (23). The mechanisms which affect the translational machinery in HepG2 are as yet undetermined.

Exposure of HepG2 cells to zinc, before incubation with copper, increased the $\mathrm{LD}_{50}$ from 750 to $1,250 \mu \mathrm{M}$ copper (Fig. 2), a protective effect that lasted for at least $30 \mathrm{~h}$ (Fig. 3). Zinc pretreatment also prevented the occurrence of reduced protein synthesis in cells exposed for $1 \mathrm{~h}$ to MEM with $1,000 \mu \mathrm{M}$ copper chloride. That this reduction in copper toxicity after zinc exposure was simply the consequence of an inhibition of copper uptake from the media was excluded (Table I). We believe that zinc's protective effect correlated with its capacity to increase the synthesis of a $10-\mathrm{kD}$ protein which can be radiolabeled biosynthetically with $\left[{ }^{35}\right.$ S $]$ cysteine (Figs. 6 and 7), but not with $\left[{ }^{35} \mathrm{~S}\right]$ methionine (Fig. 5). This suggestive identification of the protein as metallothionein was confirmed by its reactivity with rabbit anti-rat metallothionein antibody (Fig. 7) and by the finding of an increased steady-state metallothionein mRNA level (Fig. 6). Metallothionein has the capacity to bind up to $12 \mathrm{~g}$ atoms of copper per mole, and its protective role against the toxicity of copper and other heavy metals has been demonstrated in numerous studies (24). Levels of metallothionein have also been shown to be elevated in certain cell lines that have been selected for resistance to copper and other heavy metals $(20,25)$. Binding of copper by the zinc induced metallothionein is indicated by the elution profiles on HPLC gel filtration of copper and radiolabeled cysteine in metallothionein-containing fractions (Fig. 8).

We found a second lower-molecular-mass peak induced by zinc pretreatment containing copper and cysteine (Fig. 8 a). This fraction contained glutathione, as determined by thinlayer chromatography. There is evidence that glutathione may play a protective role against heavy metal toxicity (26). Moreover, increased levels of both cellular glutathione and metallothionein were found in a copper-resistant cell line (27). However, although we observed induction of glutathione synthesis after zinc pretreatment, steady-state levels of cellular glutathione were essentially unchanged from controls. Therefore, it is unlikely that glutathione could account for the observed protective effects of zinc.

We have found that the time course of zinc protection against copper toxicity correlates better with the biosynthesis of metallothionein than the steady-state level of this protein (Fig. 7). We postulate that this may reflect a requirement for protein synthesis for the incorporation of copper into this protein, consistent with earlier findings from this laboratory of reduced copper incorporation into the low-molecular-mass protein fraction of HepG2 after treatment with cycloheximide (20).

After the formation of the copper-metallothionein complex, its transfer to and subsequent sequestration by lysosomes may contribute to the protection of HepG2 cells against copper toxicity. These electron-dense bodies (Fig. 11), possess the ultrastructural characteristics of lysosomes (28). They are very similar to the electron-dense, metallothionein-containing ly- 
sosomes present in the hepatocytes of Bedlington terriers with inherited copper toxicosis $(12,29)$, and patients with advanced Wilson's disease $(1,2,30,31)$ or primary biliary cirrhosis $(32,33)$.

Mitochondrial abnormalities have been reported in hepatocytes in early stages of Wilson's disease $(1,2)$, however, no such ultrastructural changes were seen in the HepG2, and cellular energy in the form of ATP is unchanged.

Zinc treatment has been under investigation as an alternative therapy for Wilson's disease $(6,7)$. Its demonstrated ability to induce metallothionein in the enterocyte is the basis for its proposed action, resulting in the sequestration and consequent reduction of the absorption of copper from the gut (8). The evidence presented by our study demonstrates that zinc may have a direct action upon hepatocytes, thus contributing to the mitigation of copper toxicity.

\section{Acknowledgments}

We thank Irene Volenberg and Nelson Quintana for excellent technical assistance and Anna Caponigro for patient secretarial help.

These studies were supported in part by grants from the National Institutes of Health (DK-34668, DK-17702, and DK-32972) and the National Center for the Study of Wilson's Disease, Inc. Dr. Schilsky is the recipient of a National Research Service Award (DK-08151), and of an American Liver Foundation Postdoctoral Research Fellowship. Dr. Czaja is an American Liver Foundation Postdoctoral Research Fellow. Dr. Zern is the recipient of an Irma T. Hirschl Career Scientist and Sinsheimer Foundation Awards.

\section{References}

1. Sternlieb, I. 1980. Copper and the liver. Gastroenterology 78:1615-1628.

2. Scheinberg, I. H., and I. Sternlieb. 1984. Wilson's Disease. W. B. Saunders, Philadelphia. 1-171.

3. Biempica, L., H. Rauch, N. Quintana, and I. Sternlieb. 1988. Morphological and chemical studies on a murine mutation (Toxic milk mice) resulting in hepatic copper toxicosis. Lab. Invest. 59:500508.

4. Twedt, D. C., I. Sternlieb, and S. R. Gilbertson. 1979. Clinical, morphologic, and chemical studies on copper toxicosis of Bedlington terriers. J. Am. Vet. Med. Assoc. 175:269-275.

5. Scheinberg, I. H., I. Sternlieb, M. L. Schilsky, and R. J. Stockert. 1987. Penicillamine may detoxify copper in Wilson's disease. Lancet. II.95.

6. Hill, G. M., J. G. Brewer, A. S. Prasad, C. R. Hydrick, and D. E. Hartmann. 1987. Treatment of Wilson's disease with zinc. I. Oral zinc therapy regimens. Hepatology (Baltimore). 7:522-528.

7. Hoogenraad, T. U., J. van Hattum, and C. J. A. van den Hamer. 1987. Management of Wilson's disease with zinc sulphate: experience in a series of 27 patients. J. Neurol. Sci. 77:137-146.

8. Cousins, R. J. 1985. Absorption, transport, and hepatic metabolism of copper and zinc: special reference to metallothionein and ceruloplasmin. Physiol. Rev. 62:238-309.

9. Knowles, B. B., C. C. Howe, and D. P. Aden. 1980. Human hepatocellular cell lines secrete the major plasma proteins and hepatitis B surface antigen. Science (Wash. DC). 209:497-499.

10. Boyse, E. A., L. J. Old, and I. Chouroulinkov. 1964. Cytotoxic test for demonstration of mouse antibody. Methods Med. Res. 10:3947.

11. Lowry, O. H., N. J. Rosebrough, and A. L. O. Farr. 1951. Protein measurement with the Folin phenol reagent. J. Biol. Chem. 193:265-275.

12. Johnson, G. F., A. G. Morell, R. J. Stockert, and I. Sternlieb. 1981. Hepatic lysosomal copper protein in dogs with an inherited copper toxicosis. Hepatology (Baltimore). 3:243-248.

13. Towbin, H., T. Staehelin, and J. Gordon. 1979. Electrophoretic transfer of proteins from polyacrylamide gels to nitrocellulose sheets: procedure and some applications. Proc. Natl. Acad. Sci. USA. 76:4350-4354.

14. Sekune, T., and K. Ando. 1972. Fluorescent thiol reagents. V. Microfluorometry of thiol compounds with a fluorescent labeled maleimide. Anal. Biochem. 48:557-568.

15. Samuelson, A. C., R. J. Stockert, A. B. Novikoff, P. M. Novikoff, J. C. Saez, D. C. Spray, and A. W. Wolkoff. 1988. Influence of cytosolic $\mathrm{pH}$ on receptor-mediated endocytosis of asialoorosomucoid. Am. J. Physiol. 254:C829-C838.

16. Chirgwin, J. M., A. E. Pryzbyla, R. J. MacDonald, and W. J. Rutter. 1979. Isolation of biologically active ribonucleic acid from sources enriched with ribonuclease. Biochemistry. 18:5294-5299.

17. Zern, M. A., M. A. Leo, M. A. Giambrone, and C. S. Lieber. 1985. Increased type I procollagen mRNA levels and in vitro protein synthesis in the baboon model of chronic alcoholic liver disease. Gastroenterology. 89:1123-1131.

18. Lawn, R. M., J. Adelman, S. C. Bocik, A. E. Franke, C. M. Houck, R. C. Najarian, P. H. Seeburg, and K. L. Wion. 1981. The sequence of human serum albumin cDNA and its expression in $E$. coli. Nucleic Acids Res. 9:6103-6114.

19. Schmidt, C. J., D. H. Hamer, and O. W. McBride. 1984. Chromosomal location of human metallothionein genes: implications for Menkes' disease. Science (Wash. DC). 224:1104-1106.

20. Stockert, R. J., P. S. Grushoff, A. G. Morell, G. E. Bentley, H. A. O'Brien, I. H. Scheinberg, and I. Sternlieb. 1986. Transport and intracellular distribution of copper in a human hepatoblastoma cell line, HepG2. Hepatology (Baltimore). 6:60-64.

21. Freedman, J. H., R. J. Weiner, and J. Peisach. 1986. Resistance to copper toxicity of cultured hepatoma cells. J. Biol. Chem. 261:11840-11848.

22. Hernandez, O., M. A. Ballusteros, J. Domingo Mendez, and A. Rosado. 1974. Copper as a dissociating agent of liver and endometrial polysomes. Fertil. Steril. 25:108-112.

23. Hurst, R., J. R. Schatz, and R. L. Matts. 1987. Inhibition of rabbit reticulocyte lysate protein synthesis by heavy metal ions involves the phosphorylation of the alpha-subunit of the eukaryotic initiation factor 2. J. Biol. Chem. 262:15939-15945.

24. Kagi, J. H. R., and Y. Kojima, editors. 1987. Metallothionein II. Birkhäuser-Verlag, Boston. 755 pp.

25. Durnam, D. M., and R. D. Pamiter. 1984. Induction of metallothionein-I mRNA in cultured cells by heavy metals and iodoacetate: evidence for gratuitous inducers. Mol. Cell Biol. 4:484-491.

26. Meister, A. 1988. Glutathione metabolism and its selective modification. J. Biol. Chem. 263:17205-17208.

27. Freedman, J. H., M. R. Ciriolo, and J. Peisach. 1989. The role of glutathione in copper metabolism and toxicity. J. Biol. Chem. 264:5598-5605.

28. Sternlieb, I., and S. Goldfischer. 1976. Heavy metals and lysosomes. In Lysosomes in Biology and Pathology, Volume 5. J. T. Dingle and R. T. Dean, editors. Elsevier/North Holland, Amsterdam. 185-200.

29. Lerch, K., G. F. Johnson, P. S. Grushoff, and I. Sternlieb. 1985. Canine hepatic lysosomal copper-protein: identification as metallothionein. Arch. Biochem. Biophys. 243:108-114.

30. Sasa, A., H. Hayashi, A. Yagi, S. Ohguchi, R. Kidokoro, Y. Sato, and N. Sakamoto. 1986. A copper-sulfur complex in the liver of a patient with Wilson's disease. Gastroenterol. Jpn. 21:633-637.

31. Nartey, N. O., J. V. Frei, and M. G. Cherian. 1987. Hepatic copper and metallothionein distribution in Wilson's disease (hepatolenticular degeneration). Lab. Invest. 57:397-401.

32. Hanaichi, T., R. Kidokoro, H. Hayashi, and N. Sakamoto. 1984. Electron probe $\mathrm{x}$-ray analysis on human hepatocellular lysosomes with copper deposits: copper binding to a thiol-protein in lysosomes. Lab. Invest. 51:592-597.

33. Janssens, A. R., F. T. Bosman, D. J. Ruiter, and C. J. A. Van den Hamer. 1984. Immunohistochemical demonstration of the cytoplasmic copper-associated protein in the liver in primary biliary cirrhosis: its identification as metallothionein. Liver. 4:139-147. 